International Journal of Biological Sciences

ISSN 1449-2288 www.biolsci.org 2008 4(5):330-337

Short Research Communication

(C) Ivyspring International Publisher. All rights reserved

\title{
Antifungal Potential of Extracellular Metabolites Produced by Streptomy- ces hygroscopicus against Phytopathogenic Fungi
}

\section{Benjaphorn Prapagdee ${ }^{1 凶}$, Chutima Kuekulvong ${ }^{1}$ and Skorn Mongkolsuk ${ }^{2,3}$}

1. Laboratory of Environmental Biotechnology, Faculty of Environment and Resource Studies, Mahidol University, Salaya, Nakhonpathom 73170, Thailand

2. Department of Biotechnology, Faculty of Science, Mahidol University, Bangkok 10400, Thailand.

3. Laboratory of Biotechnology, Chulabhorn Research Institute, Bangkok 10210, Thailand.

$\triangle$ Correspondence to: Dr. Benjaphorn Prapagdee, Faculty of Environment and Resource Studies, Mahidol University, Salaya, Nakhonpathom 73170, Thailand. Tel: 6624415000 ext. 1319; Fax: 662441 9509; E-mail: enbrp@mahidol.ac.th

Received: 2008.06.30; Accepted: 2008.09.17; Published: 2008.09.19

Indigenous actinomycetes isolated from rhizosphere soils were assessed for in vitro antagonism against Colletotrichum gloeosporioides and Sclerotium rolfsii. A potent antagonist against both plant pathogenic fungi, designated SRA14, was selected and identified as Streptomyces hygroscopicus. The strain SRA14 highly produced extracellular chitinase and $\beta$-1,3-glucanase during the exponential and late exponential phases, respectively. Culture filtrates collected from the exponential and stationary phases inhibited the growth of both the fungi tested, indicating that growth suppression was due to extracellular antifungal metabolites present in culture filtrates. The percentage of growth inhibition by the stationary culture filtrate was significantly higher than that of exponential culture filtrate. Morphological changes such as hyphal swelling and abnormal shapes were observed in fungi grown on potato dextrose agar that contained the culture filtrates. However, the antifungal activity of exponential culture filtrates against both the experimental fungi was significantly reduced after boiling or treatment with proteinase $\mathrm{K}$. There was no significant decrease in the percentage of fungal growth inhibition by the stationary culture filtrate that was treated as above. These data indicated that the antifungal potential of the exponential culture filtrate was mainly due to the presence of extracellular chitinase enzyme, whereas the antifungal activity of the stationary culture filtrate involved the action of unknown thermostable antifungal compound(s).

Key words: Antifungal metabolites; Streptomyces hygroscopicus; Phytopathogenic fungi, Cell-free culture filtrates

\section{Introduction}

Fungal phytopathogens pose serious problems worldwide in the cultivation of economically important plants, especially in the subtropical and tropical regions [1]. Colletotrichum gloeosporioides (Penz.) and Sclerotium rolfsii (Sacc.) cause anthracnose and leaf blight or stem-rot diseases in a wide variety of agricultural crops, respectively [2,3]. Chemical fungicides are extensively used in current agriculture. However, excessive use of chemical fungicides in agriculture has led to deteriorating human health, environmental pollution, and development of pathogen resistance to fungicide. Because of the worsening problems in fungal disease control, a serious search is needed to identify alternative methods for plant protection, which are less dependent on chemicals and are more environmentally friendly. Microbial antagonists are widely used for the biocontrol of fungal plant diseases. Many species of actinomycetes, particularly those belonging to the genus Streptomyces, are well known as antifungal biocontrol agents that inhibit several plant pathogenic fungi $[4,5,6,7]$. The antagonistic activity of Streptomyces to fungal pathogens is usually related to the production of antifungal compounds $[8,9,10,11$, 12] and extracellular hydrolytic enzymes $[12,13,14$, 15]. Chitinase and $\beta-1,3$-glucanase are considered to be important hydrolytic enzymes in the lysis of fungal cell walls, as for example, cell walls of Fusarium oxysporum, Sclerotinia minor, and S. rolfsii $[4,16,17]$.

The antifungal potential of extracellular metabolites from Streptomyces against some fungi was previously reported $[6,9,18,19,20]$. However, data related to the antagonistic ability of the extracellular metabolites of Streptomyces strains to suppress the growth of the fungal pathogens C. gloeosporioides and S. rolfsii having a broad host range are limited [5]. In this article, the isolation of a Streptomyces strain from rhizosphere soils and its ability to produce extracellu- 
lar antifungal metabolite(s) against C. gloeosporioides and $S$. rolfsii has been reported. The levels of the extracellular chitinase and $\beta-1,3$-glucanase enzymes and their antifungal activity were determined at different growth phases. Additionally, this study investigated the antifungal activity of the cell-free culture filtrate of this antagonist to determine whether the production of the extracellular hydrolytic enzymes or secondary antifungal compound(s) is involved in its observed effect. The antifungal potential of extracellular metabolites produced by soil-borne Streptomyces could be exploited for its future use as a biofungicide.

\section{Materials and Methods}

\section{Fungal strains and culture conditions}

The fungal pathogens Colletotrichum gloeosporioides DOAC1690 and Sclerotium rolfsii DOAC1521 were obtained from Department of Agriculture, Ministry of Agriculture and Cooperatives, Thailand. Both the fungi tested were grown on potato dextrose agar (PDA) (Difco, USA) plates and incubated at $28^{\circ} \mathrm{C}$ for 4-6 days. Stock cultures of C. gloeosporioides and $S$. rolfsii were maintained on PDA slants and stored at 4 ${ }^{\circ} \mathrm{C}$.

\section{Isolation of soil-borne actinomycetes}

Twenty-four random rhizosphere soil samples were collected from paddy fields and orchards in the central part of Thailand and stored in sterile plastic bags. The soil samples were suspended in $25 \mathrm{ml}$ of basal salt solution $\left(5.0 \mathrm{~g} / 1 \mathrm{KH}_{2} \mathrm{PO}_{4}\right.$ and $\left.5.0 \mathrm{~g} / 1 \mathrm{NaCl}\right)$ [21] and shaken in a rotary shaker $(150 \mathrm{rpm})$ at $28^{\circ} \mathrm{C}$ for $30 \mathrm{~min}$. The soil suspension was diluted and heated at $50{ }^{\circ} \mathrm{C}$ for $6 \mathrm{~min}$. Subsequently, $0.1 \mathrm{ml}$ of diluted soil suspension was spread onto starch-casein-agar plates (soluble starch $10.0 \mathrm{~g} / \mathrm{l}$; casein $0.3 \mathrm{~g} / \mathrm{l} ; \mathrm{KNO}_{3} 2.0 \mathrm{~g} / \mathrm{l} ; \mathrm{NaCl} 2.0 \mathrm{~g} / \mathrm{l} ; \mathrm{MgSO}_{4} .7 \mathrm{H}_{2} \mathrm{O}$ $0.05 \mathrm{~g} / \mathrm{l} ; \mathrm{CaCO}_{3} 0.02 \mathrm{~g} / \mathrm{l} ; \mathrm{FeSO}_{4} \cdot \mathrm{H}_{2} \mathrm{O} 0.01 \mathrm{~g} / \mathrm{l} ; \mathrm{KH}_{2} \mathrm{PO}_{4}$ $2.0 \mathrm{~g} / \mathrm{l}$; and agar $18.0 \mathrm{~g} / \mathrm{l}$ ), which were supplemented with $50 \mu \mathrm{g} / \mathrm{ml}$ of filter-sterilized cycloheximide to inhibit fungal growth, and incubated at $28{ }^{\circ} \mathrm{C}$ for $12-14$ days. Colonies of actinomycetes on the agar plates were picked on the basis of their morphological characteristics and purified on ISP-2 agar [22]. For inducing sporulation, purified colonies were subcultured onto ISP-3 [22].

Screening for the antagonistic activity of isolated actinomycetes against phytopathogenic fungi

All the isolates were screened for their in vitro antagonism against C. gloeosporioides and S. rolfsii, according to the modified method of Crawford et al. [23]. Briefly, a 20- $\mu$ l suspension of spores (106 spores $/ \mathrm{ml}$ ) of actinomycetes strain was spotted on one side of a PDA plate and incubated at $28^{\circ} \mathrm{C}$ for 3 days. A mycelial plug of $6.0-\mathrm{mm}$ diameter from 3-days-old of each fungus was cut and transferred to an actinomycetes-pregrown PDA plate. The fungal plug was additionally placed on uninoculated PDA plates separately as control treatment. The radial fungal growth in the direction of the antagonist in both the control and the dual culture plates was measured at 4 and 6 days after incubation of $S$. rolfsii and C. gloeosporioides, respectively. The levels of inhibition were calculated by using the equation as previously mentioned by Yuan and Crawford [24].

\section{Identification of isolated antagonist}

Genus identification of the SRA14 was identified by $16 \mathrm{~S}$ rDNA sequencing. The 1498-bp fragment of $16 \mathrm{~S}$ rDNA was amplified in a thermocycler (Perkin Elmer Cetus Model 480) by using universal primers of 27f (5'-AGA GTT TGA TCC TGG CTC AG - $3^{\prime}$ ) and 1525r (5'-AAG GAG GTG ATC CAG CC-3') under the following condition: $94^{\circ} \mathrm{C}$ for $5 \mathrm{~min}, 35$ cycles of $94^{\circ} \mathrm{C}$ for $60 \mathrm{sec}, 55^{\circ} \mathrm{C}$ for $60 \mathrm{sec}, 72^{\circ} \mathrm{C}$ for $90 \mathrm{sec}$ and final extension at $72^{\circ} \mathrm{C}$ for $5 \mathrm{~min}$. Approximately 1500-bp of PCR product was directly sequenced by a BigDye terminator cycle sequencing kit (PE Applied Biosystems, USA) on an ABI 310 automated DNA sequencer (Applied Biosystems, USA). Homology of the 16s rDNA sequence of isolate was analyzed by using BLAST program from Genbank database (http: www.ncbi.nlm.gov/BLAST/).

\section{Quantitative determination of extracellular chitinase} and $\beta$-1,3-glucanase activities

The strain SRA14 was grown in ISP-2 broth with continuous shaking at $150 \mathrm{rpm}$ at $28{ }^{\circ} \mathrm{C}$ for 9 days. Cell-free supernatants were collected at 1-day intervals by centrifugation at $8,000 \mathrm{rpm}$ for $20 \mathrm{~min}$ at $4{ }^{\circ} \mathrm{C}$. Cell pellets were dried at $80{ }^{\circ} \mathrm{C}$ and weighed to determine the growth. Chitinase activity was quantitatively determined by measuring the reducing end group of N-acetylglucosamine (NAG) [25] that degraded from colloidal chitin as substrate. The estimation of chitinase activity was carried out by the procedure described by Wang et al. [26]. The $\beta-1,3$-glucanase activity was measured according to the method of Singh et al. [17] with slight modifications, using laminarin from Laminaria digitata (Sigma, USA) as substrate. The amount of glucose released by the action of $\beta$-1,3-glucanase enzyme was measured by using dinitrosalicylic acid solution [27]. Total protein concentration was assayed by the method of Bradford [28] using the Bio-Rad protein assay dry reagent (Bio-Rad, USA), with bovine serum albumin as the protein standard. 
In vitro antifungal activity of extracellular metabolites in cell-free culture filtrates

To prepare the cell-free culture filtrate, the antagonist was cultured into ISP-2 broth and incubated on an incubator shaker $(150 \mathrm{rpm})$ at $28{ }^{\circ} \mathrm{C}$. The fermentation broth was collected during the exponential and stationary phases. Cells were removed by centrifugation at $8,000 \mathrm{rpm}$ for $20 \mathrm{~min}$ at $4{ }^{\circ} \mathrm{C}$. Cell-free supernatant was filtered aseptically through a sterile membrane with $0.45-\mu \mathrm{m}$ pore size and stored at $4{ }^{\circ} \mathrm{C}$. The growth inhibitory effects of the extracellular metabolites from culture filtrates were estimated by using the radial growth inhibition assay as described previously by Prapagdee et al. [29] with some modifications. Fungal growth inhibition was expressed as the percentage of radial growth inhibition relative to the control.

\section{Fungal hyphal morphology as affected by the crude extracellular metabolites}

C. gloeosporioides or S. rolfsii were separately grown on PDA plates at $28{ }^{\circ} \mathrm{C}$ for 3 days. Fungal mycelia were aseptically deposited on the surface of microscopic slides covered with thin (5.0-mm-thick) layers of PDA containing $20 \%(\mathrm{v} / \mathrm{v})$ cell-free culture filtrate. The inoculated slides were incubated at $28^{\circ} \mathrm{C}$ in the dark for 3 days. The fungal hyphae present on the slides were stained with lactophenol cotton blue dye (Fluka, Switzerland), and subsequent changes in the morphology of young emerging hyphae were observed using a light microscope (40X).

\section{Effects of heat and proteinase $K$ on the antifungal ac-} tivity of extracellular metabolites

To investigate the stability of the antifungal metabolites, exponential and stationary culture filtrates were either treated with $0.1 \mathrm{mg} / \mathrm{ml}$ of proteinase $\mathrm{K}$ (Sigma, USA) at $37^{\circ} \mathrm{C}$ for $60 \mathrm{~min}$ or boiled for $45 \mathrm{~min}$. The inhibitory effects of the treated culture filtrates on the radial growth of $C$. gloeosporioides and S. rolfsii were determined as described above.

\section{Statistical analysis}

The means and standard deviations of the inhibition levels, radial growth, and activities of chitinase and $\beta-1,3$-glucanase were calculated. Data were analyzed by one-way analysis of variance (ANOVA). Significant differences $(p \leq 0.05)$ between the means were determined by the DUNCAN multiple range tests.

\section{Results and Discussion}

\section{Antifungal activity of a potent antagonistic Strepto-} myces strain isolated from rhizosphere soils
One hundred and forty-six strains of indigenous actinomycetes were isolated from rhizosphere soils. Among 146 strains, only 10 strains showed antagonistic ability by inhibition of the growth of both experimental fungi (Table 1). The percentages of isolated actinomycetes with antifungal activity against either C. gloeosporioides, S. rolfsii, or both fungi were $86.3 \%$, $8.9 \%$, and $6.8 \%$, respectively. Twenty-one isolates strongly inhibited the growth of C. gloeosporioides whereas two isolates were very active against $S$. rolfsii (Table 1). Only one isolate, designated SRA14, had a strong antagonistic activity to both $C$. gloeosporioides (Figure 1; a1) and S. rolfsii (Figure 1; b1). The results indicated that SRA14 grown on PDA plate released an extracellular diffusible metabolite(s) that inhibited the hyphal growth of both C. gloeosporioides and S. rolfsii. The antagonistic potential of actinomycetes to pathogenic fungi involved the production of extracellular hydrolytic enzymes and, moreover, secondary antifungal compounds were also reported [4, 10, 12]. The strain SRA14 was identified as the genus Streptomyces on the basis of its structural and morphological characteristics [22]. Analysis of the $16 \mathrm{~S}$ rDNA gene sequences showed that SRA14 is closely related to Streptomyces hygroscopicus (98\% similarity) with GenBank database accession number AB184760. Getha and Vikineswary [8] reported that Streptomyces violaceusniger G10, synonymous with S. hygroscopicus, showed a strong antagonism against F. oxysporum f.sp. cubense by producing extracellular antifungal metabolites.

Table 1 Antifungal activity of the isolated actinomycetes against $C$. gloeosporioides and $S$. rolssii

\begin{tabular}{llll}
\hline $\begin{array}{l}\text { Antifungal } \\
\text { activity }\end{array}$ & $\begin{array}{l}\text { Number of strains (\%) of soil-borne actinomycetes } \\
\text { possessing antifungal activity against the fungi test- } \\
\text { edb }\end{array}$ & $\begin{array}{l}\text { C. gloeosporioides } \\
\text { C. rolfsii }\end{array}$ & $\begin{array}{l}\text { C. gloeosporioides } \\
\text { and S. rolfsii }\end{array}$ \\
\hline+++ & $21(14.4 \%)$ & $2(1.4 \%)$ & $1(0.7 \%)$ \\
++ & $69(47.3 \%)$ & $9(6.2 \%)$ & $8(5.5 \%)$ \\
++ & $36(24.6 \%)$ & $2(1.4 \%)$ & $1(0.7 \%)$ \\
- & $20(13.7 \%)$ & $133 \%)$ & $136(93.1 \%)$ \\
\hline
\end{tabular}

The antifungal potential of isolated actinomycetes against $C$. gloeosporioides and $S$. rolfsii was assessed by dual culture technique. The levels of growth inhibition were determined by the differences between the diameters of the radial fungal growth of a control culture $\left(\gamma_{0}\right)$ and the radial fungal growth of paired-cultures $(\gamma)$ in the direction of actinomycetes as indicated by this equation; $\Delta \gamma=\gamma_{0}-\gamma$ [24].

a The ratings of inhibition levels were modified from those of El-Tarabily et al. [4].

b Each isolate was tested using five replications.

$$
\begin{aligned}
& \text { a }++\quad=\Delta \gamma \geq 20 \mathrm{~mm} \\
& ++\quad=\Delta \gamma \geq 10-19 \mathrm{~mm} \\
& +\quad=\Delta \gamma \geq 5-9 \mathrm{~mm} \\
& -\quad=\Delta \gamma<5 \mathrm{~mm} \text { (No antifungal activity) }
\end{aligned}
$$




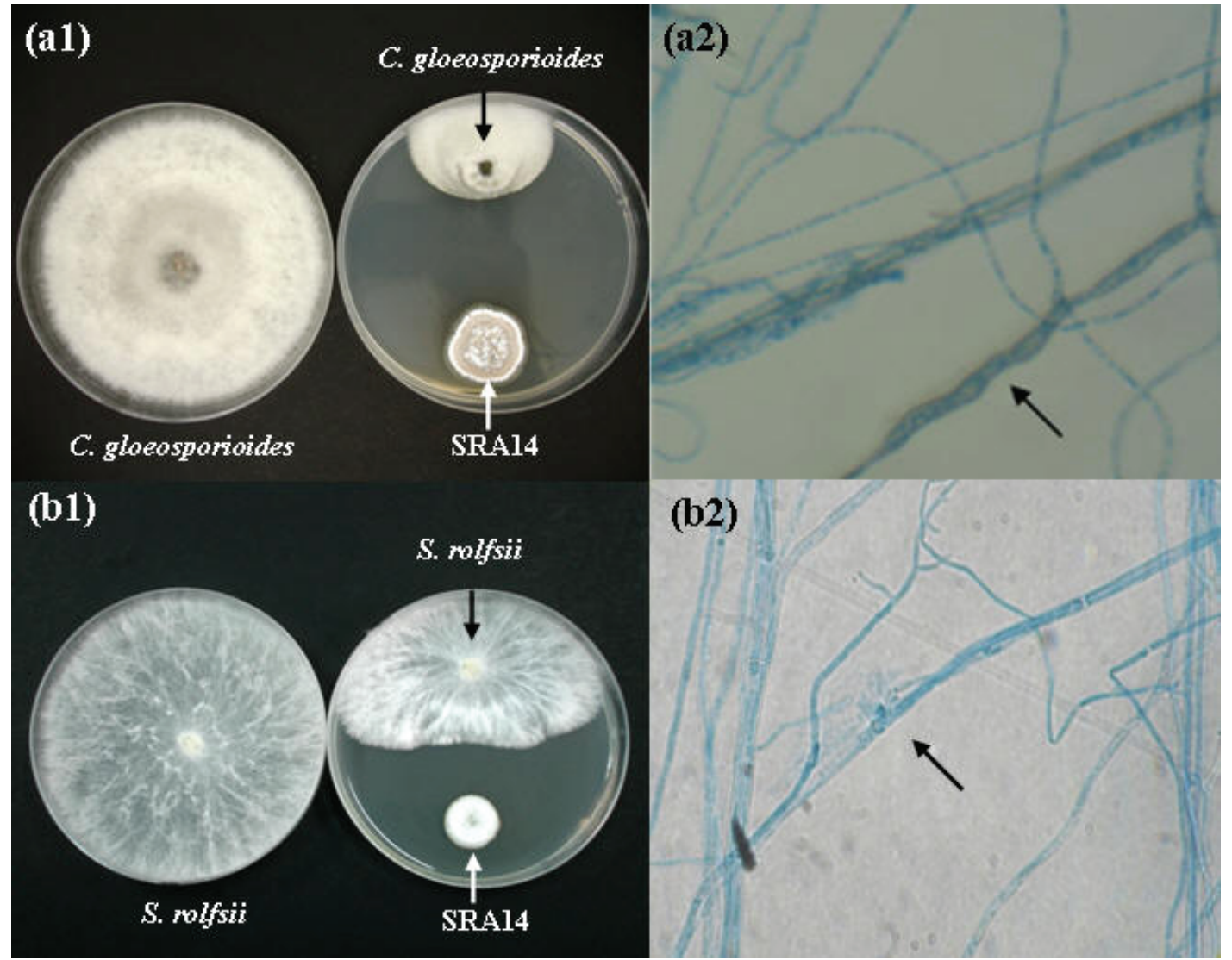

Figure 1 Antagonisms of the potent antagonist SRA14 against (a) C. gloeosporioides and (b) S. rolfsii on PDA plates. In vitro antagonism of SRA14 to the phytopathogenic fungi was evaluated on PDA plates. The strain SRA14 was grown on PDA plate for 3 days before inoculating the plate with a 6.0 -mm-diameter mycelial plug of either $C$. gloeosporioides or $S$. rolfsii and incubated at $28{ }^{\circ} \mathrm{C}$. Growth inhibitory activity was observed after 6 and 4 days of paired-culture testing for (a1) C. gloeosporioides and (b1) $S$. rolfsii, respectively, in comparison to the controls. Hyphal morphology of 3-day-old (a2) C. gloeosporioides and (b2) S. rolfsii grown on PDA amended with $20 \%(\mathrm{v} / \mathrm{v})$ stationary culture filtrate of the SRA14 was observed by light microscopes (40X).

\section{The production of extracellular chitinase and}

\section{$\beta$-1,3-glucanase enzymes by a potent antagonist}

It has been reported that antifungal mechanism of antagonists has been attributed to the action of hydrolytic enzymes such as chitinase, $\beta$-1,3-glucanase, chitosanase, and protease [21, 26, 30, 31]. The production of extracellular chitinolytic and $\beta-1,3$-glucanolytic enzymes in the strain SRA14 were determined at different growth phases. There was no chitosan or related substrate containing in ISP-2 broth. The level of chitinase was sharply increased during the exponential phase and dramatically declined when the cells entered the stationary phase (Figure 2). The strain SRA14 produced relatively high levels of chitinase (5.2 $\mathrm{U} / \mathrm{mg}$ protein) at day1 of the incubation period. Meanwhile, the highest level of $\beta-1,3$-glucanase (0.67 $\mathrm{U} / \mathrm{mg}$ protein) was found at day 2 of the incubation period and subsequently decreased slightly during the stationary phase (Figure 2). As stated in many previ- ous reports, the production of chitinase and $\beta$-1,3-glucanase enzymes by Streptomyces was related to fungal growth inhibition and the biological control of fungal pathogens was possible because of the ability of Streptomyces to degrade fungal cell walls $[4,13$, $14,15]$. It should be noted that one of the possible antifungal mechanisms of the strain SRA14 may be associated with the production of extracellular chitinase and $\beta$-1,3-glucanase enzymes.

Growth suppression of C. gloeosporioides and S. rolfsii by extracellular antifungal metabolites in cell-free culture filtrates

The increased levels of hydrolytic enzymes during the exponential phase led to an investigation of the antifungal potential of culture filtrates collected from the exponential and stationary phase cells. The radial growth of $C$. gloeosporioides and S. rolfsii was inhibited by $20 \%(\mathrm{v} / \mathrm{v})$ exponential and stationary culture filtrates in comparison with the control culture (Figure 
$3)$. The results indicated that fungal growth suppression resulted from the presence of extracellular antifungal metabolites in culture filtrates. El-Abyad et al. [19] reported that the culture filtrate of either Streptomyces pulcher or Streptomyces canescens at a concentration of $80 \%(\mathrm{v} / \mathrm{v})$ inhibited the growth of F. oxysporum f.sp. lycopersici, Verticillium albo-atrurn, and Alternaria solani. The decrease in the degree of fungal growth inhibition corresponded to the decrease in concentration of the culture filtrate (Data not shown). The growth inhibitory effect of culture filtrates decreased with the extension of fungal incubation period. Other previous studies reported that the decreases in the degree of growth inhibition were associated with the increases in the incubation period of the fungal culture $[19,30]$.

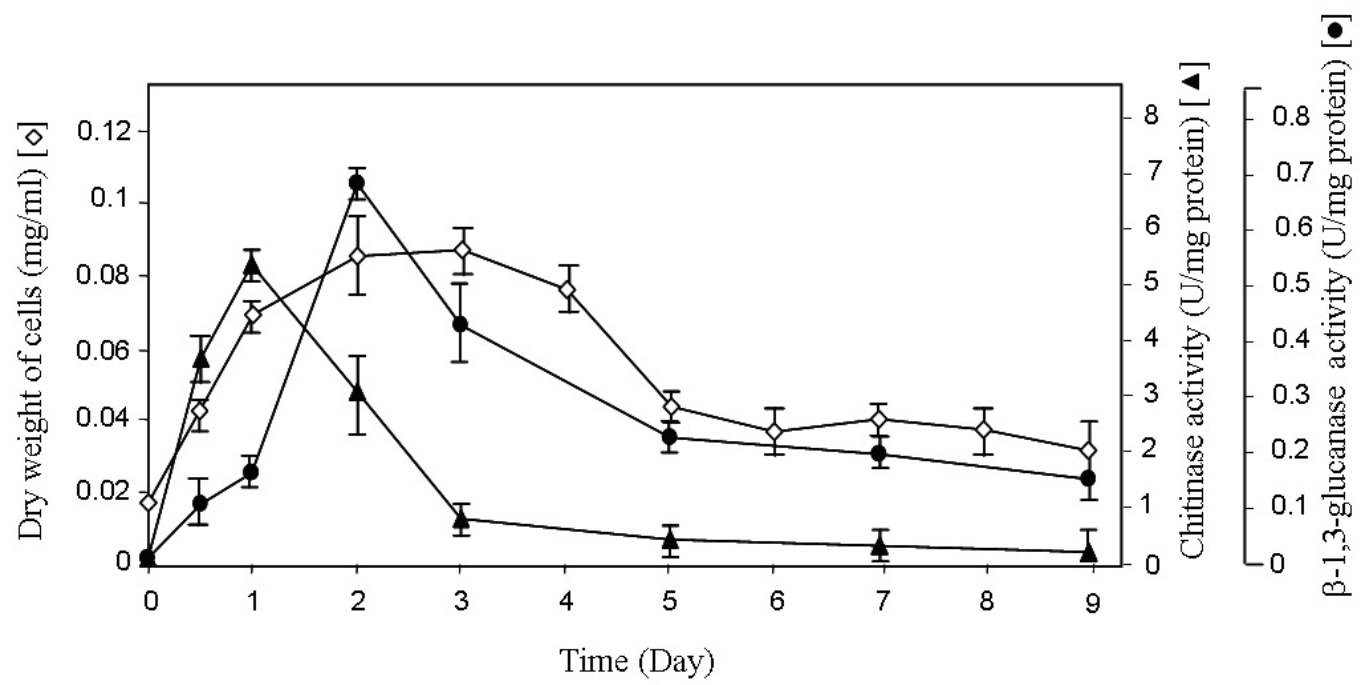

Figure 2 Time-course experiments related to growth, chitinase activity, and $\beta$-1,3-glucanase activity in the strain SRA14. The strain SRA14 was grown in ISP-2 broth. At the indicated times, cell pellets were harvested for growth determination by dry weight measurement $(\diamond)$. Cell-free supernatants were also collected for enzymatic assays. Chitinase $(\boldsymbol{\Delta})$ and $\beta$-1,3-glucanase $(\bullet)$ assays were conducted as described previously by Wang et al. [26] and Singh et al. [17], respectively. Values presented are the means and standard deviation of three independent experiments.

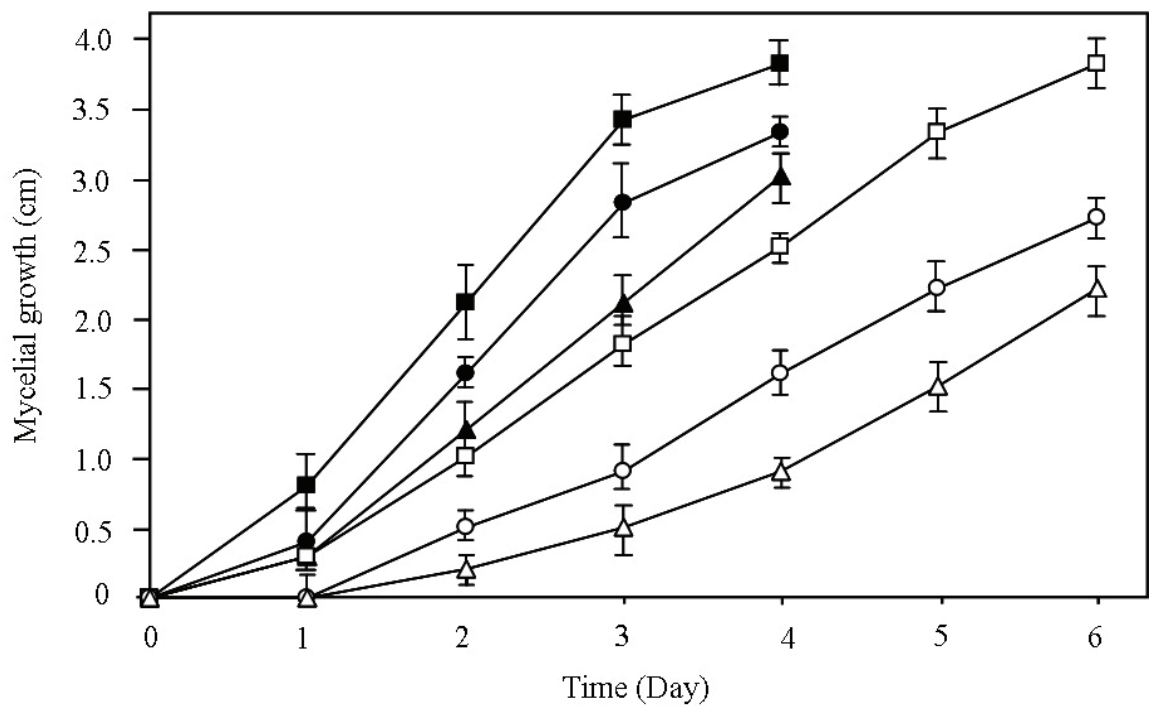

Figure 3 Antifungal effects of culture filtrates obtained from the strain SRA14 as observed by the radial growth inhibition of phytopathogenic fungi. $C$. gloeosporioides was grown on PDA plates, modified with either $20 \%$ (v/v) exponential (O) or stationary $(\Delta)$ culture filtrates. Antifungal effects of exponential $(\bullet)$ and stationary $(\boldsymbol{\Delta})$ culture filtrates on the growth of $S$. rolfsii were also tested. Control culture of $C$. gloeosporioides $(\square)$ and $S$. rolfsii ( $\square)$ were cultivated on culture filtrate-free PDA. Mycelial growth of both fungi was monitored by measuring the colony diameter at 1-day intervals. The experiment was independently repeated at least three times and representative data are shown. 
The percentages of the radial growth inhibition of $C$. gloeosporioides by the exponential and stationary culture filtrates on the day 3 of incubation were $50.0 \%$ and $72.8 \%$, respectively. The mycelial growth of $S$. rolfsii was more suppressed by the stationary culture filtrate $(38.2 \%)$ than by the exponential culture filtrate $(17.7 \%)$. Culture filtrates significantly inhibited the growth of C. gloeosporioides, which was better than the growth inhibition of $S$. rolfsii. The results indicated that the stationary culture filtrate possessed a higher antifungal potential than the exponential culture filtrate. These findings imply that the antifungal potential of the exponential culture filtrate was probably related to the increased production of hydrolytic enzymes, particularly chitinase. It has been reported that chitinase from $T$. harzianum rifai T24 was able to lysis the cell walls of $S$. rolfsii [16]. There is a possibility that the increased antifungal activity against the fungi tested in these experiments by the stationary culture filtrate of the strain SRA14 is a consequence of the production of extracellular secondary antifungal compound(s). The production of secondary antifungal compound(s) as antibiotics has been already reported in many species of Streptomyces [7, 9, 11]. Antibiotic production by $S$. hygroscopicus can inhibit a broad range of fungal pathogens such as Rhizoctonia solani, Pythium ultimum, F. oxysporum, and Sclerotinia homeocarpa $[18,20]$.

\section{Extracellular antifungal metabolites cause an abnor- mal change in the morphology of fungal hyphae}

The finding that extracellular metabolites in the culture filtrates of the strain SRA14 inhibited the growth of pathogenic fungi prompted the investigation of the effects caused by its metabolites on the growth of the hyphal structure. Light microscope investigation revealed that extracellular metabolites in the culture filtrates caused the cellular changed in hyphal morphology including hyphal swelling, distortion and cytoplasm aggregation (as marked arrow in Figure 1; a2 and b2). A greater degree of hyphal distortion was observed on PDA plate amended with $20 \%(\mathrm{v} / \mathrm{v})$ stationary culture filtrate. It has been reported that chitinase and $\beta$-1,3-glucanase enzymes are able to lyse fungal cell walls and are responsible for the suppression of fungal growth [17, 21]. According to Joo [6], Streptomyces halstedii AJ-7 produces extracellular chitinase and causes abnormal hyphal morphology. The culture filtrate of Pseudomonas aeruginosa K-187 causes growth aberration, hyphal swelling, and lysis of many fungi due to its high content of chitinase enzyme [31]. Abnormal hyphal structures such as thickness and bulbous roundedness of the inhibited fungal hyphae resulting from diffusible secondary compounds have been previously reported [11]. The antifungal antibiotics of $S$. violaceusniger G10 showed in vitro antagonistic effects against $F$. oxysporum f.sp. cubense, such as hyphal swelling and the inhibition of spore germination [8]. The fungal growth inhibition by the strain SAR14 is likely to be due to the presence of extracellular metabolites both hydrolytic enzymes and secondary antifungal compound(s).

Stability of extracellular antifungal metabolites to heat and proteinase $K$ treatment

On the basis of the results from in vitro studies, either the combination of extracellular hydrolytic enzymes and secondary antifungal metabolite(s) or the secondary antifungal metabolite(s) alone can be assumed to play a major role in the inhibition of fungal growth. To clarify this assumption, the exponential and stationary culture filtrates were treated by heating at $100{ }^{\circ} \mathrm{C}$ for $45 \mathrm{~min}$ or with proteinase $\mathrm{K}$ at $37^{\circ} \mathrm{C}$ for $60 \mathrm{~min}$ before testing of antifungal bioassay. The results showed that the antifungal activity against $C$. gloeosporioides (Figure 4a) and S. rolfsii (Figure 4b) by heat-treated and proteinase K-treated exponential culture filtrate was significantly reduced compared to the antifungal activity of the untreated exponential culture filtrate. No significant difference in the percentage of growth inhibition for both experimental fungi was observed between the heat-treated and proteinase K-treated exponential culture filtrates. The antifungal potential of the treated exponential culture filtrate against $C$. gloeosporioides and $S$. rolfsii was decreased 9.1 and 3.9 fold, respectively, in comparison with the untreated exponential culture filtrate. In contrast, there was no significant reduction in the percentage of inhibition by heat-treated and proteinase K-treated stationary culture filtrates to C. gloeosporioides (Figure 4a) and S. rolfsii (Figure 4b) compared to the untreated stationary culture filtrate.

The results of this study confirmed that the antifungal potential of the exponential culture filtrate was caused by heat labile proteins such as extracellular hydrolytic enzymes that were largely produced during the exponential phase, particularly chitinase enzyme. Fungal growth inhibition by the stationary culture filtrate was related to the presence of unknown thermostable antifungal compound(s) rather than to the presence of hydrolytic enzymes. Streptomyces violaceusniger YCDE9 was reported not only to produce the extracellular hydrolytic enzymes but also to excrete three antifungal compounds [12]. The current findings suggest that extracellular hydrolytic enzymes in the exponential culture filtrate and secondary 
thermostable compound(s) in the stationary culture filtrate of the strain SRA14 play an important role in the inhibition of the growth of $C$. gloeosporioides and $S$. rolfsii.

(a) C. gloeosporioides

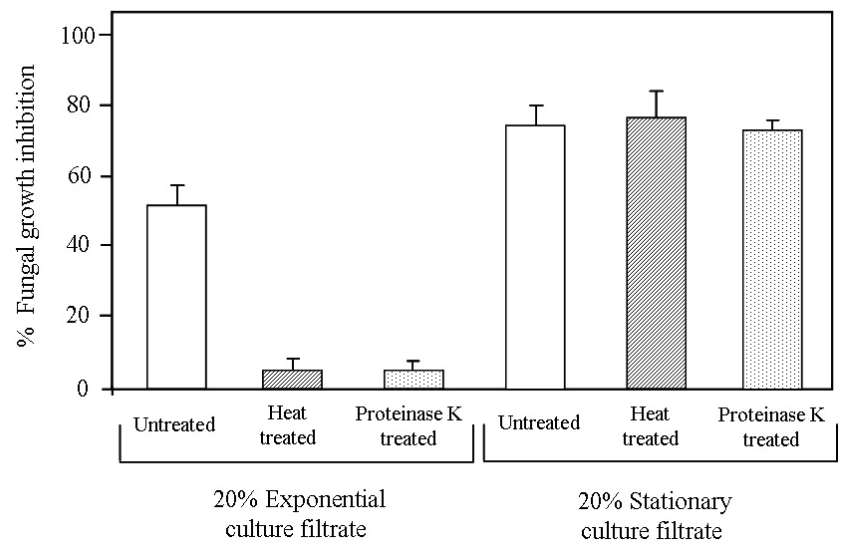

(b) S. rolfsii

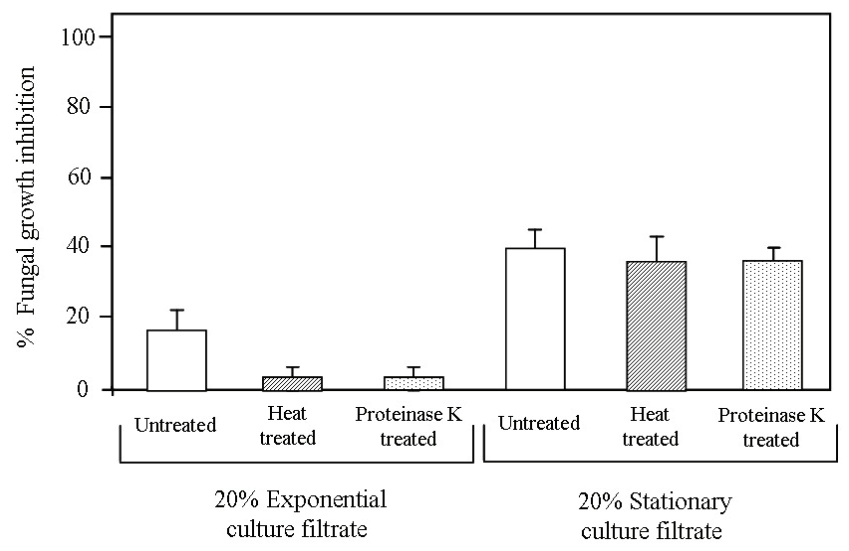

Figure 4 Effects of heat and proteinase $K$ on the antifungal activity of culture filtrates to (a) C. gloeosporioides and (b) S. rolfsii. Exponential and stationary culture filtrates from the strain SRA14 were treated with proteinase $\mathrm{K}$ at $37{ }^{\circ} \mathrm{C}$ for 60 min or boiled for $45 \mathrm{~min}$. The treated $20 \%(\mathrm{v} / \mathrm{v})$ culture filtrates were mixed with warm molten PDA and their antifungal activities against $C$. gloeosporioides and $S$. rolfsii were assessed by radial growth inhibition assay. Fungal growth was measured after 3 days of incubation and the percentage of growth inhibition was calculated. Data are presented as the mean of triplicate experiments and the error bars indicate the standard deviations.

\section{Acknowledgements}

This research project was supported by the grant from Thailand Research Fund (TRF) to B. Prapagdee (MRG4980130). The authors thank P. Siwayaprahm, K Duangmal, U. Akrapikulchart and W. Tanboon for their technical assistance.

\section{Conflict of Interests}

The authors have declared that no conflict of interest exists.

\section{References}

1. Brimner TA, Boland GJ. A review of the non-target effects of fungi used to biologically control plant diseases. Agr Ecosyst Environ 2003; 100: 3-16.

2. Gamagae SU, Sivakumar D, Wilson Wijeratnam RS, Wijesundera RLC. Use of sodium bicarbonate and Candida oleophila to control anthracnose in papaya during storage. Crop Prot. 2003; 22: 775-9.

3. Singh A, Mehta S, Singh HB, Nautiyal CH. Biocontrol of collar rot disease of betelvine (Piper betle L.) caused by Sclerotium rolfsii by using rhizosphere-competent Pseudomonas fluorescens NBRI-N6 and P. fluorescens NBRI-N. Curr Microbiol. 2003; 47: 153-8.

4. El-Tarabily KA, Soliman MH, Nassar AH, Al-Hassani HA, Sivasithamparam K, McKenna F, St J Hardy GE. Biological control of Sclerotinia minor using a chitinolytic bacterium and actinomycetes. Plant Pathol. 2000; 49: 573-83.

5. Errakhi R, Bouteau F, Lebrihi A, Barakate M. Evidences of biological control capacities of Streptomyces spp. against Sclerotium rolfsii responsible for damping-off disease in sugar beet (Beta vulgaris L.). World J Microbiol Biotechnol. 2007; 23: 1503-9.

6. Joo GJ. Production of an anti-fungal substance for biological control of Phytophthora capsici causing phytophthora blight in red-peppers by Streptomyces halstedii. Biotechnol Lett. 2005; 27: 201-5.

7. Xiao K, Kinkel LL, Samac DA. 2002. Biological control of Phytophthora root rots on alfalfa and soybean with Streptomyces. Biol Control. 2002; 23: 285-95.

8. Getha K, Vikineswary S. Antagonistic effects of Streptomyces violaceusniger strain G10 on Fusarium oxysporum f. sp. cubense race 4: Indirect evidence for the role of antibiosis in the antagonistic process. J Ind Microbiol Biotechnol. 2002; 28: 303-10.

9. Fguira LF, Fotso S, Ameur-Mehdi RB, Mellouli L, Laatsch H. Purification and structure elucidation of antifungal and antibacterial activities of newly isolated Streptomyces sp. strain US80. Res Microbiol. 2005; 156: 341-7.

10. Ouhdouch Y, Barakate M, Finance C. Actinomycetes of Moroccan habitats: Isolation and screening for antifungal activities. Eur J Soil Biol. 2001; 37: 69-74.

11. Taechowisan T, Lu C, Shen Y, Lumyong S. Secondary metabolites from endophytic Streptomyces aureofaciens CMUAc130 and their antifungal activity. Microbiology. 2005; 151: 1691-5.

12. Trejo-Estrada SR, Paszczynski A, Crawford DL. Antibiotics and enzymes produced by the biocontrol agent Streptomyces violaceusniger YCED9. J Ind Microbiol Biotechnol. 1998; 21: 81-90.

13. Mahadevan B, Crawford DL. Properties of the chitinase of the antifungal biocontrol agent Streptomyces lydicus WYEC108. Enzyme Microb Technol. 1997; 20: 489-93.

14. Mukherjee G, Sen SK. Purification, Characterization, and antifungal activity of chitinase from Streptomyces venezuelae $\mathrm{P}_{10}$. Curr Microbiol. 2006; 53: 265-9.

15. Valois D, Fayad K, Barasubiye T, Garon M, Dery C, Brzezinski R, Beaulieu C. Glucanolytic actinomycetes antagonistic to Phytophthora fragariae var. rubi, the causal agent of raspberry root rot. Appl Environ Microbiol. 1996; 62: 1630-5.

16. El-Katatny MH, Gudelj M, Robra KH, Elnaghy MA, Gübitz GM. Characterization of a chitinase and an endo- $\beta$-1,3-glucanase from Trichoderma harzianum rifai T24 involved in control of the phytopathogen Sclerotium rolfsii. Appl Microbiol Biotecnol. 2001; 56: $137-43$.

17. Singh PP, Shin YC, Park CS, Chung YR. Biological control of Fusarium wilt of cucumber by chitinolytic bacteria. Phytopathology. 1999; 89: 92-9. 
18. Chamberlain K, Crawford DL. In vitro and vivo antagonism of pathogenic turfgrass fungi by Streptomyces hygroscopicus strains YCED9 and WYE53. J Ind Microbiol Biotechnol. 1999; 23: 641-6.

19. El-Abyad MS, El-Sayad MA, El-Shanshoury AR, El-Sabbagh SM. Towards the biological control of fungal and bacterial diseases of tomato using antagonistic Streptomyces spp. Plant Soil. 1993; 149: 185-95.

20. Rothrock CS, Gottlieb D. Role of antibiosis in antagonism of Streptomyces hygroscopicus var. geldanus to Rhizoctonia solani in soil. Can J Microbiol. 1984; 30: 1440-7.

21. De Boer W, Gunnewiek PJAK, Lafeber P, Janse JD, Spit BE, Woldendorp JW. Antifungal properties of chitinolytic dune soil bacteria. Soil Biol Biochem. 1998; 30: 193-203.

22. Shirling EB, Gottlieb D. Methods for characterization of Streptomyces species. Int J Syst Bacteriol. 1966; 16: 313-40.

23. Crawford DL, Lynch JM, Whipps JM, Ousley MA. Isolation and characterization of actinomycete antagonists of a fungal root pathogen. Appl Environ Microbiol. 1993; 59: 3899-905.

24. Yuan WM, Crawford DL. Characterization of Streptomyces lydicus WYEC108 as a potential biocontrol agent against fungal root and seed rots. Appl Environ Microbiol. 1995; 61: 3119-28.

25. Imoto $T$, Yagishita K. A simple activity measurement of lysozyme. Agri Biol Chem. 1971; 35: 1154-6.

26. Wang SL, Hsiao WJ, Chang WT. Purification and characterization of an antimicrobial chitinase extracellular produced by Monascus purpureus CCRC31499 in a shrimp and crab shell powder medium. J Agr Food Chem. 2002; 50: 2249-55.

27. Miller GL. Use of dinitrosalicylic acid reagent for determination of reducing sugar. Anal Chem. 1959; 31: 426-8.

28. Bradford MM. A rapid and sensitive method for the quantitation of microgram quantities of protein utilizing the principle of protein-dye binding. Anal Biochem. 1976; 72: 248-4.

29. Prapagdee B, Kotchadat K, Kumsopa A, Visarathanonth N. The role of chitosan in protection of soybean from sudden death syndrome caused by Fusarium solani f. sp. glycines. Bioresour Technol. 2007; 98: 1353-8.

30. Chang WT, Chen YC, Jao CL. Antifungal activity and enhancement of plant growth by Bacillus cereus grown on shellfish chitin wastes. Bioresour Technol. 2007; 98: 1224-30.

31. Wang SL, Yieh TC, Shih IL. Production of antifungal compounds by Pseudomonas aeruginosa K-187 using shrimp and crab shell powder as a carbon source. Enzyme Microb Technol. 1999; 25: $142-8$. 